\title{
Mountain Survey of Amphibians and Reptiles and their Conservation Status in Manaslu Conservation Area, Gorkha District, Western Nepal
}

Biraj Shrestha ${ }^{\dagger, 1}$, Karan Bahadur Shah ${ }^{2}$

\begin{abstract}
SUMMARY
Aim The Manaslu Conservation Area (MCA), a geographically diverse protected area, is known for high diversity of flowering plants and endemism. However, information about status of herpetofauna is limited. This study aims to fill this gap by updating diversity and distribution of herpetofauna of the MCA.
\end{abstract}

Location Sirdibas, Bihi and Prok Village Development Committees (VDCs), Gorkha district, Manaslu Conservation Area (MCA).

Materials and methods We used a multi-prolonged strategy combining visual encounter survey (VES) along six transects (50om each) in Sirdibas, Bihi and Prok VDCs, patch sampling (PS) in two sites in Ghap and Prok VDCs and opportunistic observations (OO) along trekking trails from Sirdibas to Prok to document the presence of herpetofauna. We conducted questionnaire survey using photoelicitation technique (PET) $(n=30)$ to collect ethnoherpetological data.

Key Findings We prepared a checklist of 22 species of amphibian and reptile by verification of data from VES, PS, OO and literature review. The Himalayan rock lizard, Laudakia tuberculata was common in all the study sites. The Hodgson's racer - Elaphe hodgsonii was first described in the study area. The abundance of herpetofauna species decreased with increasing elevation $(r=-0.53, \mathrm{P}<0.01)$. There was a positive association between species abundances and temperature $(r=0.49, P$ $<0.01$ ). The ethnoherpetological survey revealed that the stream frogs locally called 'Paha' (genus 'Amolops', 'Chaparana' and 'Paa') were commonly consumed for food and presumed health benefits. This may impose a serious threat. We recommend similar systematic study to document and describe herpetofauna in the region.

Kerwords Amphibians; reptiles; visual encounter survey; patch sampling; opportunistic observation; photo-elicitation technique; Himalayan rock lizard; Hodgson's racer; paha.

Author Contribution BS collected field data and performed analysis. BS and KBS wrote the manuscript.

CoMPETING INTEREST Authors declare no competing interest.

Funding Nepal Academy of Science \& Technology (NAST)

\section{Short Communication}

Article History

Received 25 September 2017

Revised 25 November 2017

Accepted 17 December 2017

Academic Editor

Prakash K Paudel

\section{Correspondence}

${ }^{\dagger}$ Department of Environmental Sciences, Khwopa College, Dekocha-5, Bhaktapur, Nepal

Tel: ++977-1-6610932

E-mail: thepristinewoods@gmail. com

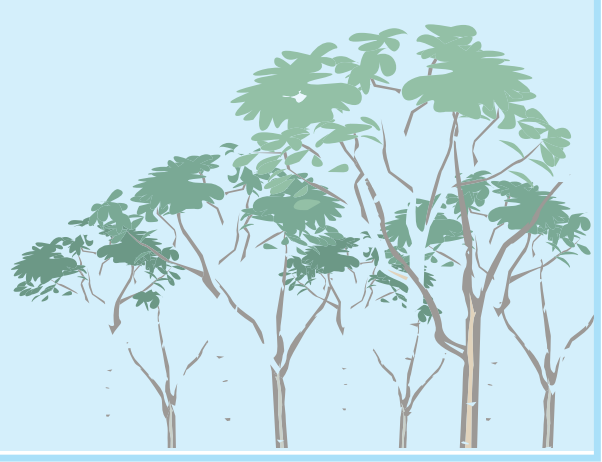

${ }^{1}$ Department of Environmental Sciences, Khwopa College, Dekocha-5, Bhaktapur, Nepal. Email: thepristinewoods@gmail.com; ${ }^{2}$ Natural History Museum, Swayambhu, Kathmandu, Nepal

\section{Introduction}

Herpetofauna are cold-blooded animals, that includes an array of species, namely, caecilians, newts, salamanders, toads, frogs, crocodiles, turtles, lizards, skinks and snakes. Herpetological study is an important part of biodiversity research because herpetofauna constitute high proportion of new species discovery and many more believed to be unknown to science (WWF 2009), nearly one in five reptile species (Bohm et al. 2013) and one-third of the global amphibian species are threatened with extinction (Baillie et al. 2004). They are threatened with extinction due to habitat loss (Marsh and Trenham 2001), climate change (Kiesecker et al. 2001) and hunting for food and pharmacopeia (Lannoo et al. 1994). Herpetofauna are often considered as bio-indicators of the environmental quality (Wang and Chan 2008) and are used to gauge the health of riparian ecosystem (Fulton 2013). Her- petofauna hold very special position on food web and energy flow as they transfer energy to higher trophic levels through the form of food they intake (Pough et al. 1998).

Herpetofauna are found in a great variety of habitats such as desert, sea, river, pond, swamp, forest floor and scrubland and thus constitute a great diversity. South Asia is rich in herpetofauna, including endemic species to the region (Das and Dijk 2013). This is because the region falls between two bio geographic realms - Palaearctic and Oriental.

Shah and Tiwari (2004) list a total of 190 species of herpetofauna in an elevation range between $80 \mathrm{~m}$ and 5490 $\mathrm{m}$. However, the distribution and abundance of herpetofauna are poorly known in Nepal. Reptiles and amphibians have traditionally been used for various human needs (Ceriaco 
et al. 2011, Pradhan 2014). Ethnoherpetology, therefore, is important to assess status of herpetofauna and their conservation. In Brazil, reptiles are used for various purposes: food, medicine, pets and decorative (Alves et al. 2012). Many tribes in India utilize herpetofauna as traditional medicine for treating different ailments (Pradhan 2014). In Nepal, amphibians and reptiles are regarded to have certain religious and cultural values in Hinduism and Buddhism (Shah and Tiwari 2004). However, there are limited research on status and distribution of such species and their ethnological use (eg. good source of protein and traditional medicine), which could be important for a well-founded conservation strategy.

Manaslu Conservation Area (MCA) is known for its sharp altitudinal ranges and diverse bioclimatic regimes. Herpetological studies in MCA are few (KMTNC 1998; Pokhrel and Thakuri 2010). This herpetological inventory aims to fill these gaps in Sirdibas, Bihi and Prok VDCs of Gorkha district, located in MCA by combining multiple techniques to ascertain species identification.

\section{Materials and Methods Study area}

The Manaslu Conservation Area $\left(1,663 \mathrm{~km}^{2}\right)$ is situated in the northern part of Gorkha district and covers sub-tropical to nival bio-climatic zone. It has a large number of streams, pastures, high altitude lakes and glaciers. The area has 19 types of ecosystems, 11 forest types, over 2,500 plant species (9 gymnosperms and 136 angiosperms), 33 mammals, 110 birds, and three species of herpetofauna in MCA (Bhuju et al. 2007). The study area covers three out of seven VDCs located in MCA (Figure 1). The Conservation Area is managed since 1998 by the National Trust for Nature Conservation (NTNC). We selected three VDCs (Sirdibas, Bihi and Prok) as the probable site for our study based on the information from literature and descriptions of local community people about presence of herpetofauna. Sirdibas VDC $\left(330 \mathrm{~km}^{2}\right)$ is situated in the southernmost part of MCA. Both Bihi $\left(122 \mathrm{~km}^{2}\right.$, mean elevation $1420 \mathrm{~m}$ ) and Prok VDCs (146 km², mean elevation 2110 m) are situated north to Sirdibas (Figure 1). Prok VDC is a gateway to Nubri valley.

\section{Field Survey}

We carried out an extensive 15 days field survey in Sirdibas, Bihi and Prok VDCs on April 2012. The presence and absence data of herpetofauna was recorded using transect visual encounter surveys (VES), patch sampling (PS) and opportunistic observation (OO). Visual encounter survey (VES) is the most popular technique for herpetofaunal surveys (Gillespie 1997). It involves in documenting species presence by walking along a designated area (transects, quadrats etc.) for prescribed time and visually searching the concerned species (Crump and Scott 1994). We laid out six transects for VES along trekking trail in three VDCs of MCA (Figure 2). Each transect was $500 \mathrm{~m}$ long. The sideways across the trekking trail were omitted as these sites were difficult to access due to precipice leading to the raging torrents of Budhi Gandaki river or steep slope on the other. We employed a patch sampling technique to survey fossorial species restricted to specific microhabitats like bushes, logs, rocks and litter. These microclimatic regimes represent patches. We used randomized patch sampling as appropriate

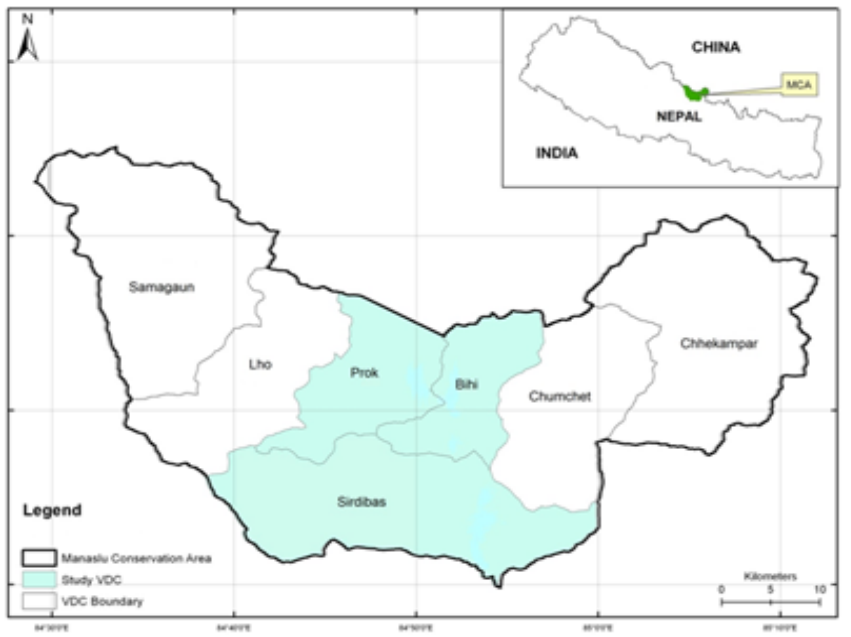

Figure 1 Location of the study area (filled with color)

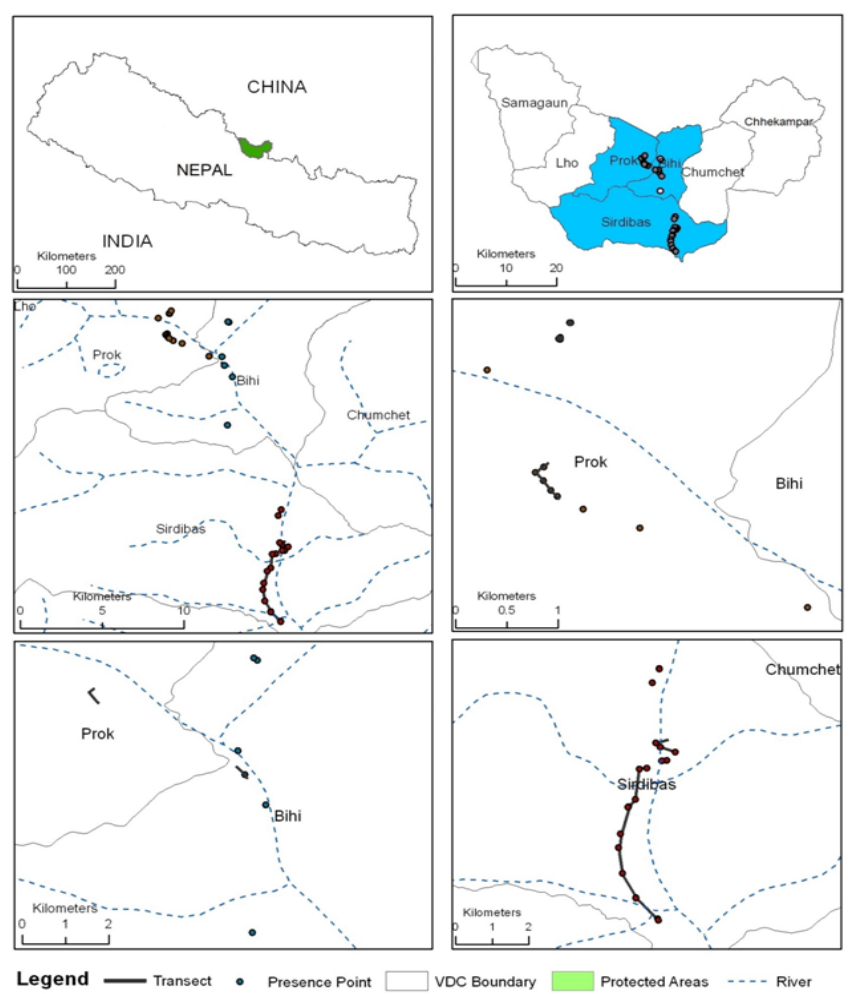

Figure 2 Map of Manaslu Conservation Area showing survey locations

(Lambert 2008). We laid two $25 \times 25 \mathrm{~m}^{2}$ quadrats in each patch and thoroughly searched for any herpetofauna presence.

Herpetofauna were surveyed during mid-day as mostly the species come out from their refuge for basking when the ambient temperature turns warmer (Hill et al. 2005). We searched each transect and patch for two hours by carefully searching presence/absence of species. We overturned rocks, poked burrows, and scanned bush, trees and leaf litters as species may have hidden underneath substrates and crevices. The survey began from Jagat (MCA's entry point) of Sirdibas VDC to Ghap of Prok VDC (Figure 2). We also searched sites opportunistically to ensure the record of species that are very rare and may not be recorded by the standard methods (Durkin et al. 2011). We recorded all species whenever possible and released them into natural habitats. Geographical coordinates, elevation and ambient air temperature were noted at each survey point. 
Table 1 A checklist of herpetofauna of MCA obtained from the data triangulation. A cross sign (X) indicates presence of the species in the study area. Abbrevations are described below.

\begin{tabular}{|c|c|c|c|c|c|}
\hline & Species & VES & PS & 00 & LR \\
\hline & Amphibians & & & & \\
\hline & Family: Bufonidae & & & & \\
\hline 1 & Duttaphrynus himalayanus (Gunther, 1864) & & & $\mathrm{x}$ & $\mathrm{X}$ \\
\hline 2 & Duttaphrynus melanostictus (Schneider, 1799) & & & & $\mathrm{X}$ \\
\hline 3 & Duttaphrynus microtympanum (Boulenger, 1882) & & & & $\mathrm{X}$ \\
\hline 4 & Duttaphrynus stomaticus (Lutken, 1864) & & & & $\mathrm{X}$ \\
\hline & Family: Ranidae & & & & \\
\hline 5 & Amolops formosus (Gunther, 1876) & & & & $\mathrm{X}$ \\
\hline & Family: Dicroglossidae & & & & \\
\hline 6 & Chaparana sikimensis (Jerdon, 1870) & & & & $\mathrm{x}$ \\
\hline 7 & Paa blanfordii (Boulenger, 1882) & & & & $\mathrm{X}$ \\
\hline 8 & Paa liebigii (Gunther, 1860) & & & & $\mathrm{X}$ \\
\hline & Reptiles & & & & \\
\hline & Family: Agamidae & & & & \\
\hline 9 & Calotes versicolor (Daudin, 1802) & & $\mathrm{X}$ & $\mathrm{x}$ & $\mathrm{X}$ \\
\hline 10 & Laudakia tuberculata (Gray, 1827) & $\mathrm{x}$ & $\mathrm{X}$ & $\mathrm{x}$ & $\mathrm{X}$ \\
\hline 11 & Oriotiaris tricarinatus (Blyth, 1854) & & & & $\mathrm{X}$ \\
\hline & Family: Scincidae & & & & \\
\hline 12 & Asymblepharus sikimmensis (Blyth, 1854) & $\mathrm{x}$ & & & $\mathrm{X}$ \\
\hline 13 & Mabuya carinata (Schneider, 1801) & & & & $\mathrm{x}$ \\
\hline & Family: Varanidae & & & & \\
\hline 14 & Varanus bengalensis (Daudin, 1802) & & & & $\mathrm{X}$ \\
\hline & Family: Boidae & & & & \\
\hline 15 & Python bivittatus (Kuhl, 1820) & & & & $\mathrm{X}$ \\
\hline & Family: Colubridae & & & & \\
\hline 16 & Amphiesma platyceps (Blyth, 1854) & & & & $\mathrm{X}$ \\
\hline 17 & Amphiesma stolatum (Linnaeus, 1758) & & & & $\mathrm{X}$ \\
\hline 18 & Boiga multifasciata (Blyth, 1861) & & & & $\mathrm{X}$ \\
\hline 19 & Elaphe hodgsonii (Gunther, 1860) & & & $\mathrm{x}$ & \\
\hline 20 & Oligodon erythrogaster (Boulenger, 1907) & & & & $\mathrm{X}$ \\
\hline 21 & Xenochrophis sanctijohannis (Boulenger, 1890) & & & & $\mathrm{X}$ \\
\hline & Family: Viperidae & & & & \\
\hline 22 & Trimeresurus albolabris (Gray, 1842) & & & & $\mathrm{X}$ \\
\hline
\end{tabular}

VES = Visual Encounter Survey, PS = Patch Sampling, OO = Opportunistic Observation, LR = Literature Review (KMTNC 1998, Shah and Tiwari 2004, Pokhrel and Thakuri 2010).

\section{Ethnoherpetology}

First, the potential key informants for the interview were identified using snowball sampling method (Hagai 2006). Snowball sampling is a non-probability sampling technique where respondents who display a similar interest are selected. We consulted conservation officers of MCA, students, teachers, farmers, hoteliers, frog hunters and the traditional healers - the Amji to garner information on local herpetofauna and ethnoherpetological knowledge. We used convenience sampling method for interviews to minimize the time consumed during the social survey. Convenience sampling collects information from respondents accessible and available to the researcher in a short time. We selected a total of 30 respondents. Each respondent was asked about presence/absence of species by using photo-elicitation technique. Ethnoherpetological information was collected for identified species during interview (Bigante 2010).

\section{Data Analysis}

We compiled data from field survey and literature review, and prepared a checklist of herpetofauna using 'Data Triangulation' method that allows to validate information from multiple sources in the same study (Hussein 2009). All the observed species were identified using morphological description provided in the field guide (Shah and Tiwari 2004). We consulted Mr Gernot Vogel to identify and verify unidentified species.

Species occurrence locations were projected in the map of the study area using Arc GIS 9.3 version. We determined species richness by counting the number of different species per sampling effort and species abundance as frequency of species per sampling effort.

\section{Results}

A total of 22 species of herpetofauna have been prepared from MCA (Table 1). The checklist included 8 species of amphibian representing three families (Duttaphrynus, Ranidae and Dicroglossidae) and 14 species of reptiles representing six families (Agamidae, Scincidae, Varanidae, Boidae, Colubridae \& Viperidae). Altogether five species of herpetofauna (Duttaphrynus himalayanus, Calotes versicolor, Laudakia tuberculata, Asymblepharus sikimmensis and Elaphe hodgsonii) were directly observed in three VDCs. We documented 21 species from literature review.

The highest abundance of herpetofauna was in Sirdibas VDC ( $\mathrm{n}=41)$. Laudakia tuberculata was spotted during day 


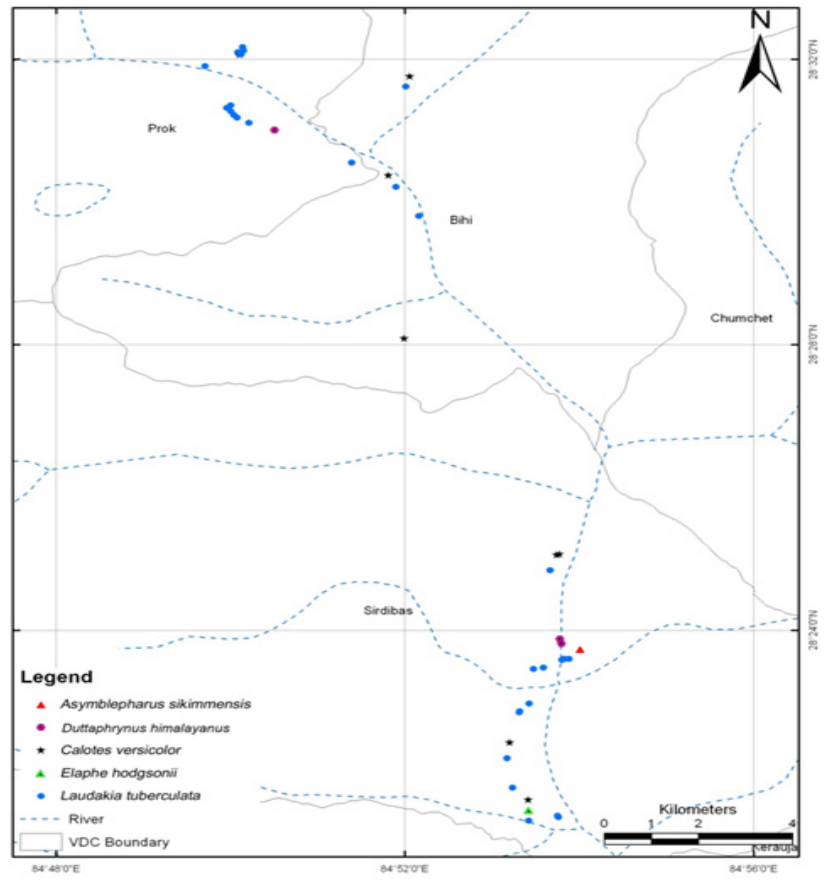

Figure 3 Distribution of herpetofauna in the study area

light basking on rocks/boulders, in human settlements and farmlands. Species abundance was comparatively low in Bihi VDC $(n=9)$ and Prok VDC $(n=15)$. However, there are high species richness in Sirdibas $(n=5)$ than Bihi $(n=2)$ and Prok $(\mathrm{n}=3)$. Elaphe hodgsonii has been confirmed for the first time from Sirdibas VDC of MCA in this study. The herpetofauna were recorded between an altitudinal range of $1438 \mathrm{~m}$ and $2665 \mathrm{~m}$ adjacent to the Budhi Gandaki river and its tributaries (Figure 3). Species observed were found clumped together in Sirdibas, from Jagat to Philim while very few in Bihi and evenly encountered across Prok VDC.

There was a negative correlation between species abundance and elevation, ( $\mathrm{r}=-0.532, \mathrm{P}<0.01$ ) (Figure 4). However, species abundance and temperature were significantly positively associated $(\mathrm{r}=0.49, \mathrm{P}<0.01$ ) (Figure 5 ). We found that herpetofauna had ethnological use for food (48\%), medicine (48\%) and religious value (4\%). The stream dwelling frogs called Paha of genus Amolops, Chaparana and Paa were exploited for food due to its unparalleled taste and are believed to have certain health benefits to cure for common ailments like Diarrhoea, dysentery, vomiting, stomachache, cold, fever, headache, urinary problems etc. (Figure 6).

\section{Discussion}

A checklist of 22 species of herpetofauna is an update of herpetofauna diversity in the middle mountain region of MCA. The record of 65 individuals from five species (one amphibian and four reptiles) suggests that less observed diversity of herpetofauna in field survey is probably influenced by time of our visit (pre-monsoon). The low rainfall during pre-monsoon period could limit for species detection (Pradhan 2007). However, 'Data Triangulation Technique' has largely contributed to produce a checklist of 22 species in our study. This strategy is useful to validate the findings and update existing herpetological knowledge (Nanhoe and Ouboter 1987, Shah 2001, Pokhrel and Thakuri 2010).

Calotes versicolor, has been recorded from an altitude of $2512 \mathrm{~m}$ in our study which is higher than previously

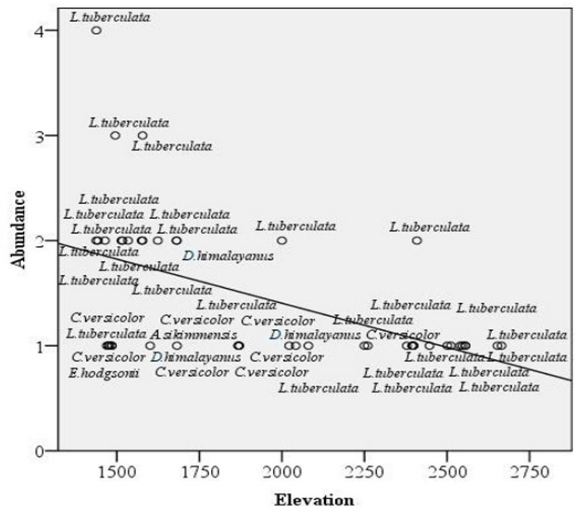

Figure 4 Scatter plot showing a linear association between the species abundance and elevation in three VDCs (Sirdibas, Bihi and Prok) in MCA

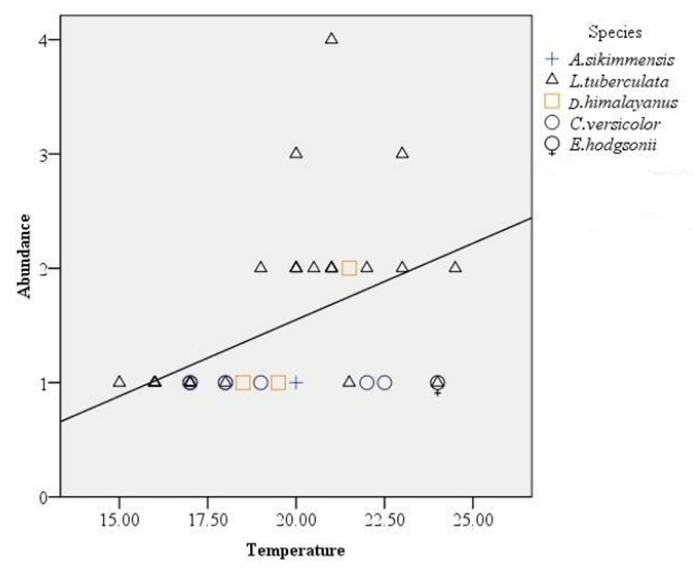

Figure 5 Scatter plot showing a linear association between the species abundance and temperature in three VDCs (Sirdibas, Bihi and Prok) in MCA

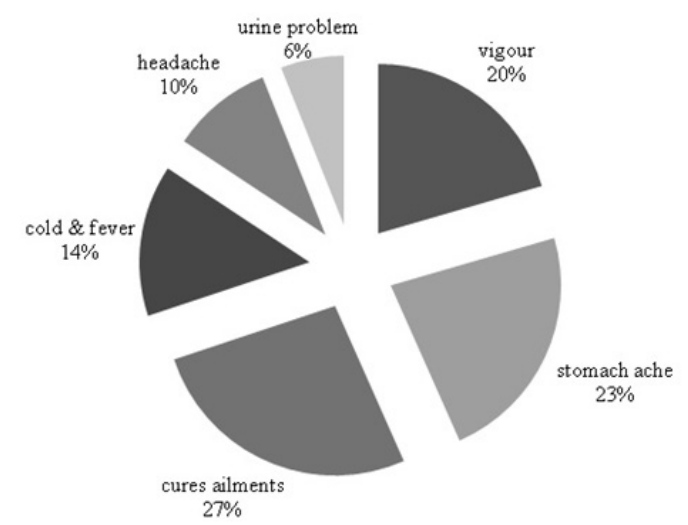

Figure 6 Medicinal use of Paha frogs

reported elevation (1660 m - Nanhoe \& Ouboter's (1987) and $1950 \mathrm{~m}$ - Shah (2001)). Generally, C versicolor is found under the elevation of $2000 \mathrm{~m}$ in diverse terrestrial habitats (Shah and Tiwari 2004). The positive correlation between species abundance and elevation suggests that temperature may have important effects via primary productivity and influence on body temperature.

Humans have been using herpetofauna for food, medicine, religion and livelihood for a long time (Shah and Tiwari 2004). The stream frogs (Paha) are widely hunted in montane regions. Frog's meat is tasty and is rich in protein (Shah and Tiwari 2004). Local people use various methods 
for processing the frog's meat (sun-baking, smoking on fire, drying in shade, deep oil fry etc.) before its consumption. Paha from the genus Chaparana, Megophrys and Paa are consumed as delicacy, protein supplements and therapeutic purposes even in the southern Annapurna region of Kaski district (Shah 2001).

The overexploitation should be regulated through promotion of conservation education programs especially the dissemination of herpetofauna's importance which would curb the deliberate killings of these neglected creatures. The Manaslu Conservation Area Project Committee should prioritize monitoring and conservation of herpetofauna. The existing brooks and cascades are important for mountain frogs including bushes, vegetation and forests for the reptiles. Such habitats must be protected to ensure the survival of these herpetofauna.

\section{Acknowledgements}

This study took place under the Climate Change Research Grant Program of Climate \& Development Knowledge Network (CDKN) and Nepal Climate Change \& Knowledge Management Center (NCCKMC), Nepal Academy of Science \& Technology (NAST). The field work in Manaslu Conservation Area (MCA) has been permitted by National Trust for Nature Conservation (NTNC), Khumaltar. Department of Environmental Science, Khwopa College provided necessary logistics support and other facilities. The staff members of MCA, Philim office provided useful information about study area. Dorje Thakuri and his family and Chimik Namgyal provided assistance during the field work. Pramod P Awal helped with statistical analyses. Madan Suwal helped with spatial maps production. Carl Jackson mentored from UK throughout the grant program. Gernot Vogel, Germany verified all the identified species. Environmental Graduates in Himalaya (EGH) and NAST contributed for refinements of research work. The authors highly acknowledge the support, guidance and encouragement received from these organizations and personnel.

\section{References}

Alves et al. 2012. A zoological catalogue of hunted reptiles in the semiarid region of Brazil. Journal of Ethnobiology and Ethnomedicine, 8:27.

Baillie, J.E.M., Hilton-Taylor, C. and Stuart, S.N. (Editors) 2004. 2004 IUCN Red List of Threatened Species. A Global Species Assessment. IUCN, Gland, Switzerland and Cambridge, UK. Xxiv + 191 pp.

Bhuju, U. R., P. R. Shakya., T. B. Basnet, and S. Shrestha. 2007. Nepal Biodiversity Resource Book - Protected Areas, Ramsar Sites and World Heritage Sites. International Centre for Integrated Mountain Development (ICIMOD) \& Ministry of Environment, Science and Technology (MOEST), Kathmandu, Nepal.

Bohm et al. 2013. The conservation status of the world's reptiles. Biological Conservation. 157:372-385. https:// doi.org/10.1016/j.biocon.2012.07.015

Bignante, E. 2010. The use of photo-elicitation in field research. EchoGéo. doi:10.4000/echogeo.11622

Ceriaco, L. M., M. P. Marques., N.C. Madeira., C. M., VilaVicosa, and P. Mendes. 2011. Folklore and traditional ecological knowledge of geckos in Southern Portugal: implications for conservation and science. Journal of Ethnobiology and Ethnomedicine, 7(26):1-9.

Crump, M. L. and Scott, N. J. Jr. Visual Encounter Surveys. In: Measuring and monitoring biological diversity (1994). Smithsonian Institution Press, Washington.

Das, I., and Dijk, P. P. V. 2013. Species Richness and Endemicity of the Herpetofauna of South and South East Asia. The Raffles Bulletin of Zoology, 29:269-277.

Durkin, L., M. Steer, and E. Belle. 2011. Herpetological surveys of forest fragments between Montagne D Ambre National Park and Ankarana Special Reserve, Northern Madagascar. Herpetological Conservation and Biology, 6(1):114-126.

Fulton, J. 2013. Herpetofauna as Indicator Species in the Health of Riparian Buffer Zones. Department of Natural Sciences, The University of Virginia's College at Wise. Metamorphosis, 1-10.

Gillespie, G. R. 1997. Survey design and management prescriptions for the giant burrowing frog (Heleioporus australiacus) and the suffering frof (Mixophyes balbus). Wildlife Research, Arthur Rylah Institute, Department of Natural Resources and Environment, Victoria.

Hagai, K. 2006. Global surveys or multi-national surveys? On sampling for global surveys. In Thoughts for the Globalization and Social Science Data Workshop. Retrieved from; http://medcontent.metapress.com/ index/A65RM03P4874243N.pdf

Hill, D., Fasham, M., Tucker, G., Shewry, M., \& Shaw, P. (Eds.). (2005). Handbook of Biodiversity Methods survey, evaluation and monitoring. Cambridge University Press. pp. 573.

Hussein, A. 2009. The use of Triangulation in Social Sciences Research: Can qualitative and quantitative methods be combined? Journal of Comparative Social Work, 1:1-12. International Centre for development oriented Research in Agriculture (ICRA). 2007. Rural Appraisal Methods - Approaches. In ICRA Learning Materials:1-7.

Kiesecker, J. M., A. R. Blaustein, and L. K. Belden. 2001. Complex causes of amphibian population declines. Nature 410:681-684

KMTNC 1998. Project Proposal for Manaslu Conservation Area. Lalitpur, Nepal:1-81.

Lambert, M. 2008. Amphibians and Reptiles:1-12.

Lannoo, M. J., K. Lang, T. Waltz, and G. S. Philips. 1994. An altered amphibian assemblage: Dickinson County, Iowa, 70 years after Frank Blanchard's survey. American midland Naturalist 131:311-319.

Marsh, D. M., and P. C. Trenham. 2001. Metapopulation dynamics and amphibian conservation. Conservation Biology 15:40-49.

Nanhoe, L. M. and P.E. Ouboter. 1987. The Distribution of Reptiles and Amphibians in the AnnapurnaDhaulagiri Region (Nepal). Zool. Verh. Leiden 240:3100.

Pokhrel, G. K., and S. Thakuri. 2010. Quick Survey of Herpetofauna in Manaslu Conservation Area, Nepal. Companion for Amphibians and Reptiles of Nepal website: http://www.caron.org.np

Pough, F.H., R.M. Andrews, J.E. Cadle, M.L. Crump, A.H. Savitzky, and K.D. Wells. 1998. Herpetology. Prentice Hall, Upper Saddle River, NJ.

Pradhan, B. K. 2007. Disaster Preparedness for Natural 
Hazards: Current Status in Nepal. International Centre for Integrated Mountain Development (ICIMOD), Kathmandu:1-69.

Pradhan, S., D. Mishra., and K.R. Sahu. 2014. Herpetofauna used as traditional medicine by tribes of Gandhamardan Hills Range, Western Orissa, India. International Journal of Research in Zoology:1-4.

Shah, K. B. 2001. Herpetofauna and Ethnoherpetology of the Southern Annapurna Region, Kaski District, Nepal. Journal of Natural History Museum, 20:106-128.
Shah, K.B., and S. Tiwari. 2004. Herpetofauna of Nepal - A Conservation Companion. IUCN Nepal, Kathmandu Nepal.

Wang, Y., and F. Chan. 2008. An Inventory of Herpetofauna on State Conservation Lands in the Cumberland Plateau of Northern Alabama. Alabama Agricultural and Mechanical University:i-115.

WWF. 2009. The Eastern Himalayas Where Worlds Collide. New Species Discovery. Living Himalayas Initiative. Pp. 1-33.

\section{Citation}

Shrestha B, Shah KB (2017) Mountain Survey of Amphibians and Reptiles and their Conservation Status in Manaslu Conservation Area, Gorkha District, Western Nepal. Conservation Science, 5: 13-18

\section{Biography}

Biraj Shrestha holds MS in Environmental Science from Tribhuvan University, Nepal. He has been actively involved in the study and conservation of herpetofauna across the country since 2012 .

Prof. Karan B. Shah worked at Natural History Museum, Swayambhu, Kathmandu, Nepal. He has extensively worked for the study of amphibians and reptiles in Nepal for more than 35 years. 